\title{
City Trees and Municipal Wi-Fi Networks: Compatibility or Conflict?
}

\author{
Igor Lacán and Joe R. McBride
}

\begin{abstract}
Conflict between city trees and infrastructure remains a problem in urban forestry. Municipal Wi-Fi, a citywide wireless computer network, may become a part of urban infrastructure, and because trees can diminish Wi-Fi signals, potential exists for conflict between urban trees and municipal Wi-Fi. This study examines attenuation of Wi-Fi signals in the City of Mountain View, California, U.S. by positioning a wireless-equipped computer so that trees obstructed the line-of-sight (LOS) between the computer and a Wi-Fi access point. Signal attenuation ranged from $<2 \mathrm{~dB}$ to $19 \mathrm{~dB}$ (mean: $5.6 \mathrm{~dB}$ ), depending on the number and types of trees present. Although trees significantly attenuated signals, they did not diminish the average signal strength below $-75 \mathrm{dBm}$ (the minimum for a Wi-Fi connection) in any of the tests. A general linear model $\left(r^{2}=0.55\right)$ indicated that some tree characteristics (tree size, canopy depth, leaf type), but not others (number of trees in LOS, presence of leaves, leaf size, and shape) helped explain variation in signal attenuation. As long as the effect of urban trees is taken into account during planning of Wi-Fi networks, trees should not interfere with municipal Wi-Fi operation.

Key Words: Interference; Urban Infrastructure; Wireless Network; Wi-Fi.
\end{abstract}

The sometimes-problematic interaction between urban trees and city infrastructure has been a longstanding difficulty in the practice of urban forestry and remains a perennial topic of arboricultural research. The most common example - the "roots/ pavement conflict" (e.g., cracks in pavement around street trees (Wagar and Barker 1983; Lesser 2001) - illustrates the difficulties of determining the ultimate causes of the problem (Sydnor et al. 2000), preventing the conflict, and managing it when it occurs (Randrup et al. 2001). Suggestions for resolving treeinfrastructure conflicts (e.g., Costello and Jones 2003) have included (1) changing the design of either the infrastructure or of the tree-planting-setup (e.g., flexible pavements, root barriers); (2) changing the tree species to those better "suited" to the infrastructure; or (3) changing tree maintenance practices. The idea of making more substantial modifications to urban infrastructure to make it more compatible with trees has recently taken hold, as evidenced by the development of structural soils and structural cells (Grabosky and Bassuk 1995; Urban 2008).

One new technology that may become a part of future urban infrastructure is a citywide wireless computing network. Today, most such networks are based on the 802.11 standards (Dobkin 2005), also known as the wireless local area network (WLAN) or "Wi-Fi," and operate on $2.4 \mathrm{GHz}$ (for 802.11b, and $802.11 \mathrm{~g}$ network protocols) and $5 \mathrm{GHz}$ microwave frequencies (for $802.11 \mathrm{a}$, a less common protocol). In the U.S., city governments first became interested in municipal 802.11 networks ("municipal Wi-Fi") in the early 2000s, and despite some recent difficulties with funding such operations (Kim 2008), this technology remains of interest to many cities today (e.g., Oklahoma City 2008). Potential uses for municipal Wi-Fi include connecting different city offices to one another and to employees in the field. The latter application could be especially valuable as both a standard communication link for nonemergency personnel (e.g. public works crews could access site plans or databases on-location) and as a backup for the radio and data transmission systems currently used by the police and fire services.

The most visible element in a typical municipal Wi-Fi network is a set of wireless routers, also known as "access points" or APs, distributed throughout the city (often installed on light poles) that allow individual users to connect their Wi-Fi equipped laptop or desktop computer to the wireless network. The APs then connect either directly, or through one another in what is known as a "mesh network," to a wired router that is connected to the internet.

Positive aspects of municipal Wi-Fi include flexibility (compared to wired networks), low cost (compared to other wireless systems such as cellular data services), potential for rapid deployment, backwards-compatibility (with older laptop and desktop computers), and familiarity to users (Dobkin 2005). In addition, concerns with radio frequency (RF) exposure are lessened, as the wireless routers' operating power is low, usually restricted to $1 \mathrm{~W}$, or $<1 / 500$ that of a cellular telephone tower (Dobkin 2005; see end of article for a note on signal-measurement units). However, this characteristic of Wi-Fi APs - low radiated power - also severely restricts the range of the wireless link. The AP-to-user range varies from a theoretical maximum of $3.5 \mathrm{~km} \mathrm{(2.2} \mathrm{mi)} \mathrm{(cf.} 70 \mathrm{~km} \mathrm{(43.5} \mathrm{mi)} \mathrm{for} \mathrm{cell} \mathrm{phones,} \mathrm{to} \mathrm{a}$ practically-achievable outdoor maximum of less than $200 \mathrm{~m}$ ( $219 \mathrm{yds}$ ); indoor ranges can be even shorter (Dobkin 2005). The range restriction occurs because for the wireless link to function, the RF signal must reach the receiver with some minimum of power (usually $-75 \mathrm{dBm}$ ) after diminishing (attenuating) from (1) passage through air ("free-space loss") and (2) passage through or refraction around the objects in its path (Dobkin 2005). 
Urban trees are a possible obstruction to the Wi-Fi signal, and the potential for trees to interfere with microwave signals has been recognized by RF engineers. Perras and Bouchard (2002) evaluated fading of RF signals that passed through tree canopies and found that mean attenuation was $21.8 \mathrm{~dB}$ for a signal passing through a $20 \mathrm{~m}(65 \mathrm{ft})$ span of foliated broadleaf canopies (Acer and Malus) and $12.6 \mathrm{~dB}$ when the signal passed through a $25 \mathrm{~m}$ (82 ft) deep conifer canopy (Picea spp.). Notably, signal attenuation was considerably lower $(14.9 \mathrm{~dB})$ when the broadleaf trees were defoliated. Regarding the effect of foliage size and tree architecture, the authors concluded that greatest signal attenuation occurred "when the size of the obstructions in the foliated path and the wavelength of the signal passing through $(\approx 12 \mathrm{~cm}$ at $2.5 \mathrm{GHz})$ are similar in size" (p. 271). Dalley and colleagues (1999) evaluated the effect of moisture in trees, and calculated that a wet tree attenuated the signal considerably more (loss of $18 \mathrm{~dB}$ ) than a dry tree (loss of $11 \mathrm{~dB}$, both at $3.5 \mathrm{GHz}$ - a somewhat higher frequency than used in municipal Wi-Fi).

What both of the above studies indicated to RF engineering professionals (Dobkin, pers. comm.) was the need to increase the density of APs in an outdoor network to compensate for the presence of trees (which reduce the maximum usable computer-to-AP distances from any one AP). However, both of these studies used a purpose-built experimental setup. They did not evaluate an actually-operating wireless network or attempt to simulate the perspective of a typical computer user with a wireless-equipped laptop.

The purpose of this study was to evaluate how urban trees affect the performance of a municipal WLAN network operating with the $802.11 \mathrm{~b}$ Wi-Fi protocol. A focus was placed on the computer-to-AP component of the network (the one most likely to be affected by trees) and evaluated the degree of interference of a tree in relation to its characteristics (canopy size, leaf size, leaf presence, leaf type). A simple setup was used (laptop computer with a wireless-network card) to simulate the experience of a user trying to connect to the internet using a municipal WiFi network from a public space, such as a sidewalk or a park.

\section{MATERIALS AND METHODS}

The study was carried out in the City of Mountain View, on the San Francisco Peninsula (Northern California, U.S.; $37^{\circ} 25^{\prime} 19^{\prime \prime} \mathrm{N}, \quad 122^{\circ} 5^{\prime} 4^{\prime \prime} \mathrm{W}, \quad 32 \mathrm{~m}$ (105 ft) elevation; 72,000 residents). The city climate is mediterranean, with the average high temperatures ranging from $14-26^{\circ} \mathrm{C}\left(58-79^{\circ} \mathrm{F}\right)$, and the average lows from $4-13^{\circ} \mathrm{C}\left(39-57^{\circ} \mathrm{F}\right)$. Most of the yearly rainfall [average: $40 \mathrm{~cm}(15.71$ in $)$ ] occurs during the winter months (November-March), while at least two summer months (July, August) are typically, completely dry.

In August 2006, a municipal Wi-Fi known as "Google-Fi" was established in the city, operated by the Google Corporation (which is headquartered in Mountain View). Users can connect (without charge, as of 2009) to Google-Fi through any of approximately 400 APs mounted on $10.5 \mathrm{~m}$ tall (34.5 ft) lightposts throughout the city (a coverage map can be found online: http://wifi.google.com/city/mv/apmap.html). The APs (MetroMesh 5320 wireless routers) are made by Tropos Networks Corp. (Sunnyvale, California) specifically for outdoor use and can operate in either $2.4 \mathrm{GHz}$ or $5 \mathrm{GHz}$ frequency bands. The network was primarily intended for outdoors access; for indoor use, a "bridge" device is recommended as the network was not set up to provide enough signal strength to pass through building materials. However, the signal-diminishing effect of urban trees was taken into account when the network was planned, as is typically done for outdoor Wi-Fi networks (Blais and Kruse, pers. comm.).

To simulate conditions that might be experienced by a typical user, a PC laptop computer was used (Gateway MX3210; Gateway Inc., Irvine, California, U.S.) with a Windows XP Home operating system (Microsoft Corp., Redmond, Washington, U.S.), and equipped with an $802.11 \mathrm{~b}$ add-on wireless card (Belkin ConnectPlus 128 in the PC-card slot; Belkin International Inc., Compton, California, U.S.). Note that in some respects (limited wireless-protocol and frequency capabilities, older Wi-Fi hardware and software) the equipment for this study represented one of the least-capable options available in 2007. That is, most WiFi users have a better-performing computer and wireless card, and these results represent a "worst-case" of the WLAN system performance. Measurements were taken of signal strength, RF noise level, and signal-to-noise ratio (SNR) using Network Stumbler software (v. 0.4.0, by Marius Milner), which can detect individual APs and record their signal parameters. The data was then transferred to SigmaStat 3.1 and SigmaPlot (Systat Software, Richmond, California, U.S.) for analysis and plotting.

To evaluate how urban trees and their characteristics affect municipal Wi-Fi signals, the laptop was positioned so that trees-varying in number, species, size, and leaf characteristics - were located between the computer and the AP (Figure 1). Records were taken of the signal, noise, and SNR for approximately five minutes (about 300 data points at 60 measurements per minute) and called this the "tree" condition (tree blocking the line of sight to the AP). The laptop was then moved so that there was a clear line of sight (LOS) to the AP (but the distance remained the same) and again recorded signal strength for five minutes to obtain measurements under the "clear" condition. The difference between the average signal ( $\Delta$ Signal) recorded under the clear condition and that recorded under the tree condition represented the attenuation caused by the tree. All measurements were taken during daylight hours, dry weather, and in calm wind. Measurements on foliated trees were carried out in late May 2007, and were repeated on the same trees in winter (when deciduous trees were defoliated), in February 2008.

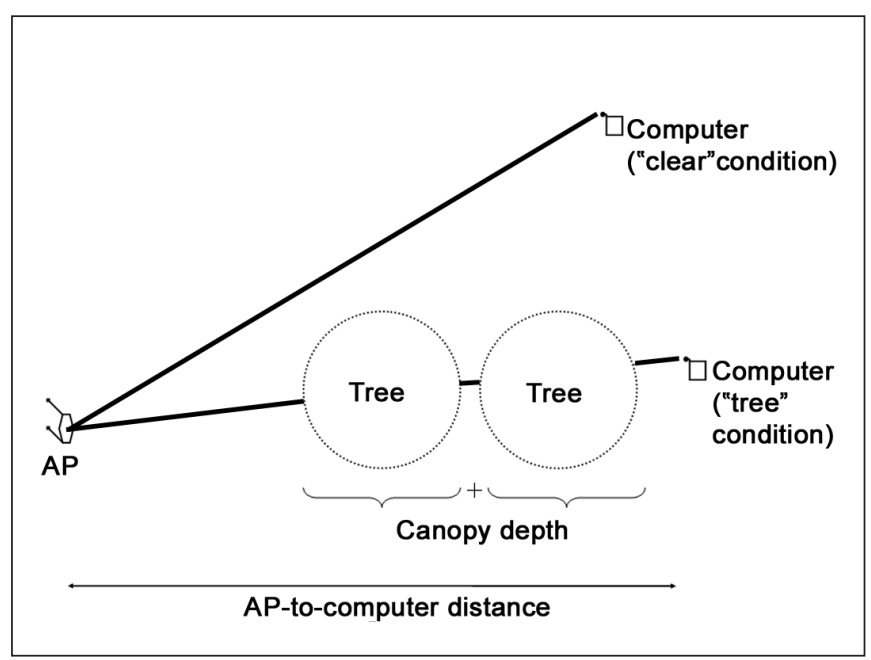

Figure 1. Schematic of the experimental setup (plan view). 
To evaluate whether the recorded signal and noise values were significantly different $(\alpha=0.05)$ between "clear" and "tree" conditions, a paired t-test was used with each AP as a replicate $(n=7)$. This test was repeated in winter as well, both on all APs $(n=7)$ and also only on the APs obscured by the defoliated deciduous trees $(\mathrm{n}=5)$. Where more than one measurement was taken at an AP (i.e., attenuation measured at several distances), the signal measurements were averaged, and the averages used in the paired t-test.

The study sites were selected to include the most common tree species in the area: all species (except Pinus pinea) are among the ten most common urban trees in the San Francisco Bay area (Laćan and McBride, unpublished). The study was further refined to present a variety of tree sizes (small: juvenile Platanus $\times$ acerifolia; mid-sized: Liquidambar styraciflua, Pistacia chinensis, Prunus cerasifera; large: Liriodendron tulipifera, Pinus pinea, $P$. radiata, and Sequoia sempervirens). The AP-computer distances selected [20-150 m (65-492 ft)] were those that would be typically encountered by a municipal Wi-Fi user, given the density of APs in Mountain View. The study measured and recorded the following tree characteristics: leaf type (needle/broadleaf), canopy depth (horizontal distance along the line from AP to computer that was obscured by the tree canopy), and the number of trees between the computer and AP. Sixteen leaves on each tree were also sampled, by the taking of four leaves from each cardinal side $(\mathrm{N}, \mathrm{E}, \mathrm{S}, \mathrm{W})$ of the tree, between 1.5 and 5.5 $\mathrm{m}(5-18 \mathrm{ft})$, or between $1.5 \mathrm{~m}(5 \mathrm{ft})$ and the top of the tree for the small $P . \times$ acerifolia trees. The average leaf area (in $\mathrm{mm}^{2}$ )

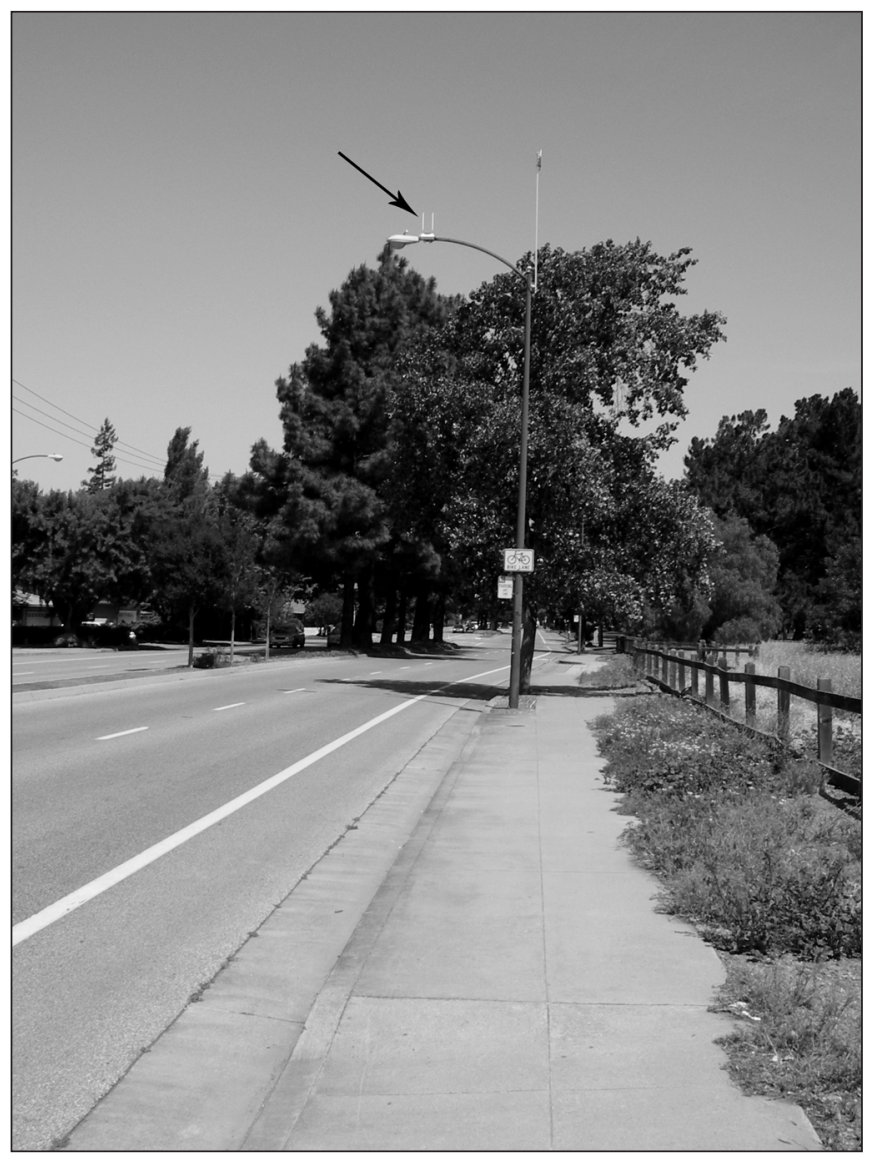

Figure 2a. "Clear condition," AP visible (the white box with two aerials, on the horizontal arm next to the lamp; arrow). was estimated by multiplying the two longest axes of the leaf blade $\left(10^{3} \mathrm{~mm}^{2}=1.55 \mathrm{in}^{2}\right)$. The study authors also determined the ratio of longest to shortest dimension of each leaf. These two approximations of leaf size and shape allowed the examination of the possible importance of leaf architecture to signal attenuation (previously suggested by Perras and Bouchard 2002).

A general linear model (GLM) was used to evaluate the relative contribution of each parameter to describing the observed signal attenuation, noise difference (attenuation), and SNR difference. The attenuation values were used in the GLM rather than the signal and SNR values (which vary with distance from AP), which would have allowed us to eliminate the AP-computer distance from GLM in case multi-colinearity with other variables (specifically, crown depth) had been detected (it was not). GLM was constructed using a backwards-stepwise procedure $(\alpha=0.05$; F-toenter: 4.00; F-to-remove: 3.90 ) in SigmaStat 3.1 software package.

\section{RESULTS}

Wi-Fi signal attenuation (loss) was observed when one or more trees were present in the signal path (Table 1, Figures 3-7), ranging from $<2 \mathrm{~dB}$ in the case of three small, newly planted trees [2 m (6.6 ft) tall Platanus $\times$ acerifolia, planted $10 \mathrm{~m}(33 \mathrm{ft})$ apart] to almost $19 \mathrm{~dB}$ in the case of seven large conifers [> 30 m (98 ft) tall Pinus radiata and Sequoia sempervirens, planted 7-8 $\mathrm{m}$ (23-26 ft) apart]. The average attenuation caused by trees (broadleaf and conifer) in-leaf was $5.6 \mathrm{~dB}$, whereas defoliated

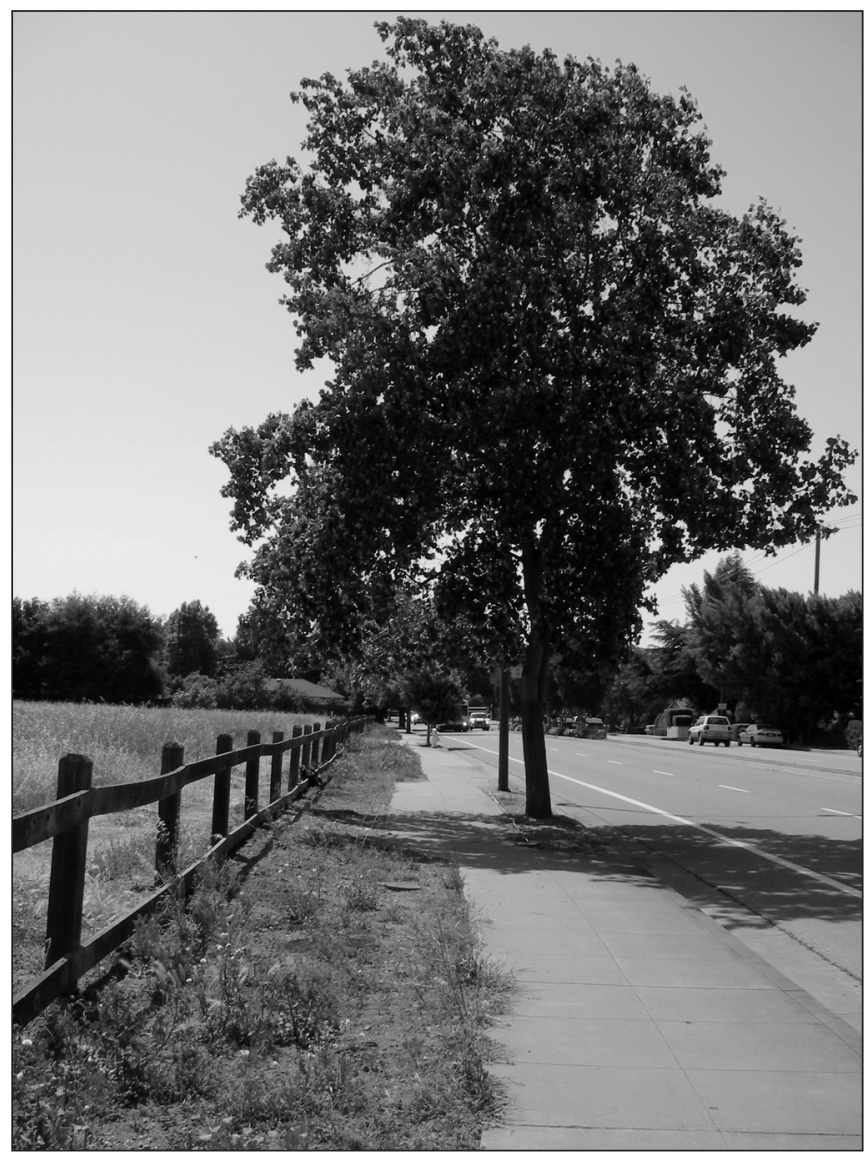

Figure 2b. "Tree condition," AP obscured by L. tulipifera (lower part of the light pole visible to the left of the tree trunk). 
broadleaf trees caused a slightly lower signal loss of $4.8 \mathrm{~dB}$. The measured attenuation (Table 1) represented a significant difference in signal strength (tree in LOS versus a clear LOS) for the 7 APs evaluated both in the summer $(P=0.009)$, and in winter (all trees: $P<0.001$; defoliated broadleaf trees only: $P=0.009$ ).

Notably, in none of the 28 measurements did the tree-caused attenuation reduce the (average) received signal strength below $-75 \mathrm{dBm}$ (the minimum for a reliable Wi-Fi connection). The received signal approached $-75 \mathrm{dBm}$ in two cases: (1) with nine $10 \mathrm{~m}$ tall Liquidambar styraciflua in LOS, causing a $7.6 \mathrm{~dB}$ at-

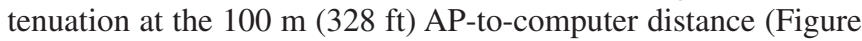
6); and (2) with seven large conifers in LOS, causing an $18.7 \mathrm{~dB}$

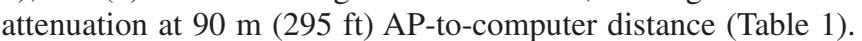

Presence of trees in LOS had little effect on RF noise. The slight reduction in measured noise $(0.03$ to $0.2 \mathrm{~dB})$ with trees in LOS was not statistically significant in either season, and the differences were so small as to be below the minimum-detectable values in the outdoor environment $( \pm 0.5 \mathrm{~dB}$; Dobkin, pers. comm.).

GLM analysis (Table 2) indicated that the three tree characteristics useful in explaining attenuation were consistent for SNR $\left(r^{2}=0.65\right)$ and signal strength $\left(r^{2}=0.55\right)$ : tree size (class), and tree leaf type (broadleaf or conifer), with tree canopy depth also contributing to the model but with a much smaller coefficient. The model-building procedure indicated that none of the measured variables significantly explained variation in RF noise.

When canopy depth, a factor indicated by GLM as important in signal and SNR variation, was plotted against signal attenuation (Figure 7), a linear relationship was observed, albeit with only modest fit [attenuation $=3.1+0.11 *$ canopy depth $(\mathrm{m}) ; \mathrm{r}^{2}=0.23$ ]

\section{DISCUSSION}

This is the first study to examine the effect of multiple tree characteristics on wireless signal transmission in the context of a currently-operational municipal Wi-Fi network. The urban trees considered in this study measurably attenuated the microwave signal, but did not reduce the signal strength below the minimum required for the wireless link $(-75 \mathrm{dBm})$. That is, the trees did not interfere with the practical operation of the municipal WLAN, thus meeting the engineering objective of the network planners (see below).

The calculated signal attenuation was rather low, ranging from almost none in the cases of the newly planted $P . \times$ acerifolia, to low $(<10 \mathrm{dBm})$ in case of medium-sized and even some large trees (L. styraciflua, S. sempervierns, respectively). The greatest attenuation was observed with a dense and deep [75 m (246 ft) canopy depth] "screen" of tall conifers (mostly S. sempervirens), which is unlikely to be experienced very often in a typical urban landscape. The second-greatest attenuation was observed in the case of a single large tulip poplar (L. tulipifera), having a dense canopy and leaves with dimensions almost equivalent to the wavelength of the Wi-Fi signal: $12 \mathrm{~cm}$ (4.7 in). It also is interesting to note the drooping habit of the L. tulipifera leaves and compare the similarly-sized but horizontally-oriented $L$. styraciflua leaves, which appeared to produce much smaller attenuation.

Trees had little effect on RF noise, which is not surprising because RF noise is caused by presence of other RF sources (e.g., cellular telephone towers, microwave ovens, two-way radios; Dobkin 2005). The slight decrease in RF noise with trees in LOS was expected (as the other RF sources are also attenuated by trees; Dobkin, pers. comm.), but proved to be insignificant.

Table 1: Tree characteristics and signal parameters (in dB) measured in a municipal Wi-Fi network in Mountain View, California.

\begin{tabular}{|c|c|c|c|c|c|c|c|c|c|}
\hline Location & Tree sp. & $\begin{array}{l}\text { Leaf size } \\
(\mathrm{mm} \times \mathrm{mm})\end{array}$ & $\begin{array}{l}\text { \# of } \\
\text { trees } \\
\text { in } \\
\text { LOS }\end{array}$ & $\begin{array}{l}\text { Canopy } \\
\text { depth } \\
(\mathrm{m})\end{array}$ & $\begin{array}{l}\text { Dist. } \\
\text { to AP } \\
(\mathrm{m})\end{array}$ & $\begin{array}{c}\Delta \text { Signal }^{\mathrm{z}}, \\
\text { summer } \\
\text { Clear - Tree } \\
\text { in leaf }\end{array}$ & $\begin{array}{c}\Delta \text { Signal, } \\
\text { winter } \\
\text { Clear - Tree } \\
\text { defoliated }\end{array}$ & $\begin{array}{c}\Delta \text { Noise, } \\
\text { summer } \\
\text { Clear - Tree } \\
\text { in leaf }\end{array}$ & $\begin{array}{c}\Delta \text { Noise, } \\
\text { winter } \\
\text { Clear - Tree } \\
\text { defoliated }\end{array}$ \\
\hline Bernardo & Platanus & $100 \times 100$ & 11 & 24.5 & 150 & -0.3 & 3.5 & 0.2 & 0 \\
\hline Street & $\times$ acerifolia & $\begin{array}{c}\text { to } \\
160 \times 180\end{array}$ & $\begin{array}{l}6 \\
3\end{array}$ & $\begin{array}{c}14 \\
6.5\end{array}$ & $\begin{array}{l}90 \\
30\end{array}$ & $\begin{array}{l}-1 \\
1.9\end{array}$ & $\begin{array}{l}3.2 \\
3.2\end{array}$ & $\begin{array}{r}0.3 \\
-0.1\end{array}$ & $\begin{array}{l}0.1 \\
0.7\end{array}$ \\
\hline $\begin{array}{l}\text { Bernardo } \\
\text { Street }\end{array}$ & $\begin{array}{l}\text { Prunus } \\
\text { cerasifera }\end{array}$ & $40 \times 80$ & 4 & 23 & 90 & 7.4 & 8.7 & -0.3 & -0.7 \\
\hline Cuesta Park & $\begin{array}{l}\text { Liriodendron } \\
\text { tulipifera }\end{array}$ & $120 \times 120$ & 1 & 3 & $\begin{array}{l}30 \\
10\end{array}$ & $\begin{array}{l}13.1 \\
11.8\end{array}$ & $\begin{array}{l}11 \\
2.7\end{array}$ & $\begin{array}{l}0 \\
0.4\end{array}$ & $\begin{array}{l}-1 \\
-1.7\end{array}$ \\
\hline Villa Street & $\begin{array}{l}\text { Pistacia } \\
\text { chinensis }\end{array}$ & $\begin{array}{c}70 \times 20 \\
(240 \times 170)\end{array}$ & $\begin{array}{l}4 \\
3\end{array}$ & $\begin{array}{l}41 \\
22\end{array}$ & $\begin{array}{l}54 \\
23\end{array}$ & -- & -- & $\overline{0.9}$ & $-\overline{0}$ \\
\hline Cuesta Park & $\begin{array}{l}\text { Pinus radiata, } \\
\text { Sequoia } \\
\text { sempervirens }\end{array}$ & $\begin{array}{c}100 \times 1.5 \\
18 \times 40 \\
(150 \times 20)\end{array}$ & $\begin{array}{l}7 \\
3 \\
1\end{array}$ & $\begin{array}{l}75 \\
35 \\
10\end{array}$ & $\begin{array}{l}90 \\
45 \\
20\end{array}$ & $\begin{array}{r}18.7 \\
5.1 \\
2.1\end{array}$ & $\begin{array}{r}14 \\
5.6 \\
2.2\end{array}$ & $\begin{array}{l}-0.1 \\
-1.2 \\
-0.5\end{array}$ & $\begin{array}{r}1.1 \\
-0.3 \\
1.2\end{array}$ \\
\hline Cuesta Park & $\begin{array}{l}\text { Pinus } \\
\text { pinea }\end{array}$ & $140 \times 1.5$ & 2 & 25 & 60 & 4 & 9.4 & 0.3 & -0.1 \\
\hline & \multicolumn{2}{|c|}{ Average attenuation: } & (defol & \multicolumn{2}{|c|}{ (all trees: $n=7$ ): } & $5.3^{y}$ & $\begin{array}{l}5.6^{y} \\
4.8^{y}\end{array}$ & $-0.03^{x}$ & $\begin{array}{l}-0.04 \\
-0.20\end{array}$ \\
\hline
\end{tabular}

${ }^{2}$ Negative values indicate a stronger signal (or lower noise) with tree(s) in LOS

${ }^{y}$ Significant differences $(P<0.05)$ in signal level between clear $\&$ tree condition.

${ }^{x}$ Differences of $<0.5 \mathrm{~dB}$ cannot be measured reliably in the outdoor environment. 


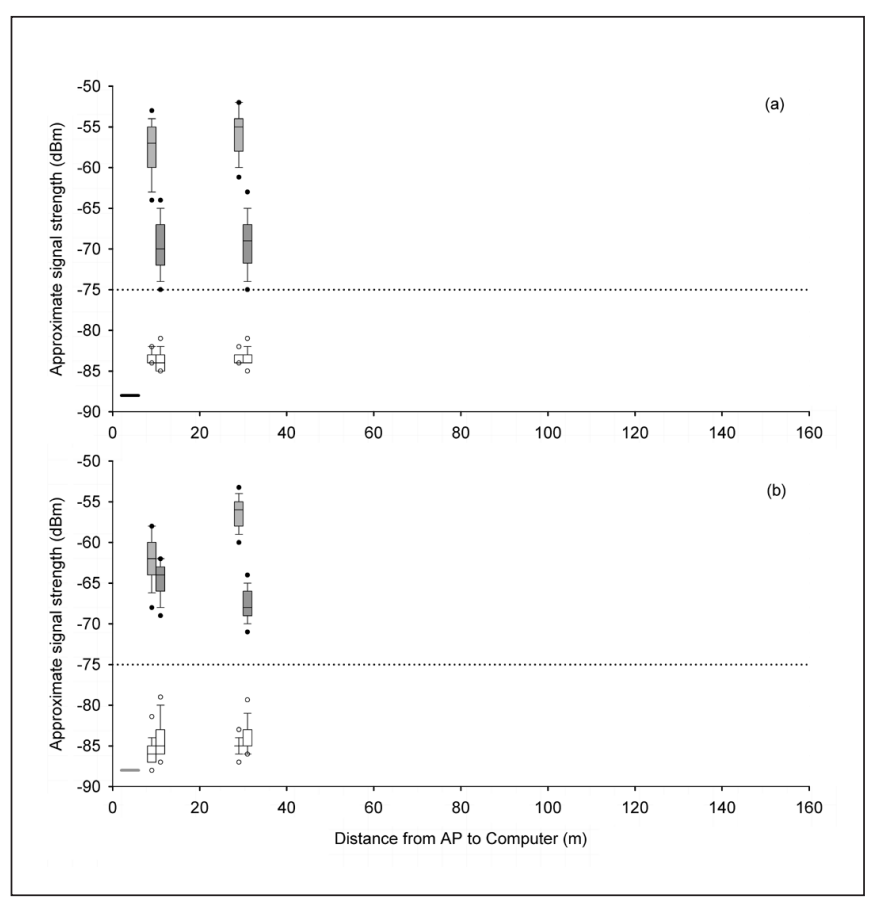

Figure 3. Effect of a single large broadleaf tree (Liriodendron tulipifera, tree shown in Figure 2); in-leaf (a), and defoliated (b), on signal and noise levels, at two AP-computer distances. Each boxplot summarizes $\approx 5$ minutes of signal and noise data. Legend: light grey: signal - clear condition; dark grey: signal - tree condition; corresponding noise data in white boxes under each signal box. Extent of tree canopy shown by the thick line placed at about $-88 \mathrm{dBm}$ (black line: tree in leaf; grey line: tree defoliated). The minimum required signal strength $(-75 \mathrm{dBm})$ shown by dotted line.

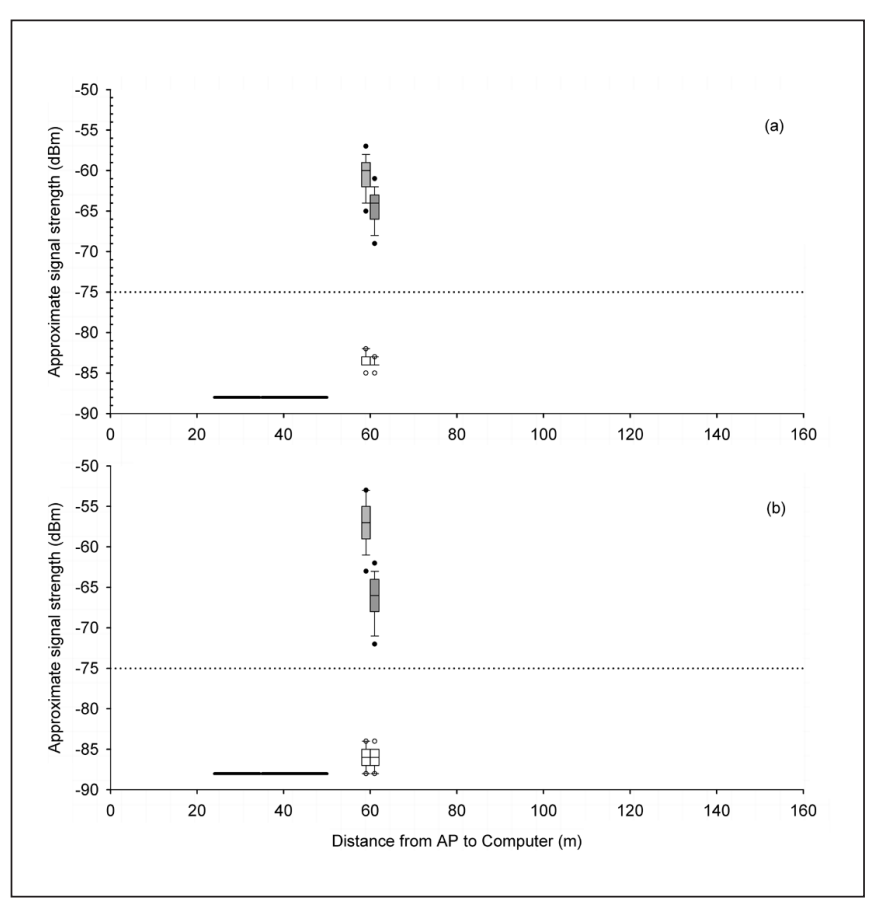

Figure 4. Effect of two large conifer trees in a park (Pinus pinea) on signal and noise levels in summer (a), and in winter (b). Legend as in Figure 3.
Tree characteristics that helped explain variation in signal attenuation were depth and size of the obstruction (both tree size or canopy distance), and (concordant with previous studies) leaf type (broadleaf versus conifer; cf. Perras and Bouchard 2002). On the other hand, leaf area and shape were similar among the trees tested and thus poorly explained the variability in signal strength relative to other independent variables.

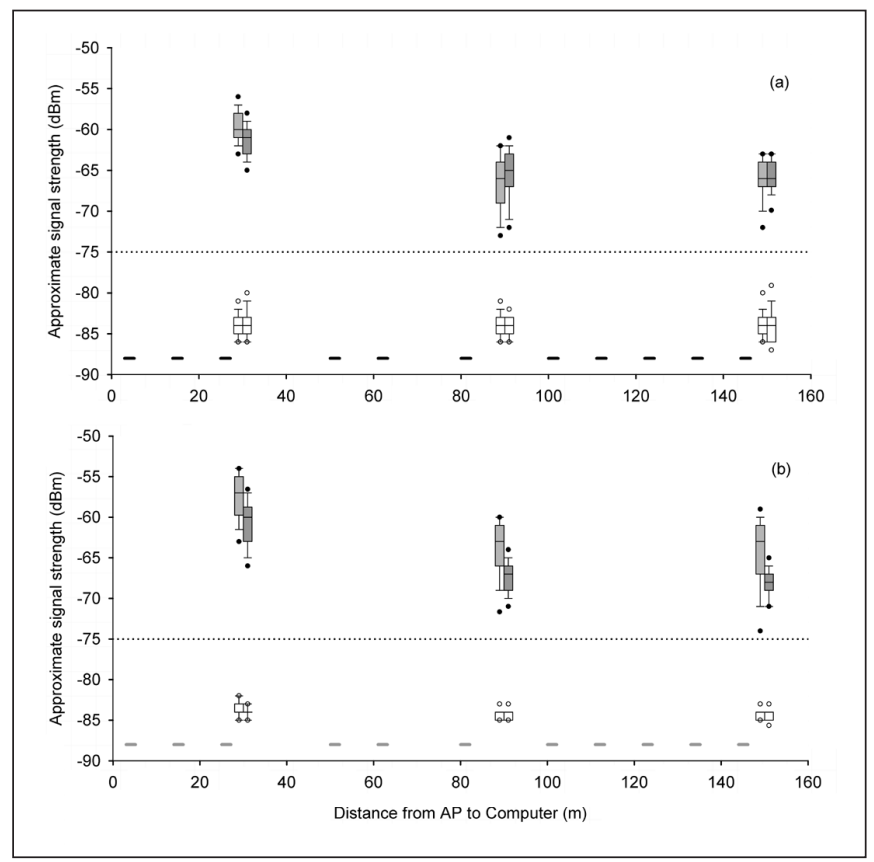

Figure 5. Effects of small street trees (Platanus $x$ acerifolia) on signal and noise levels $(3,6$, and 11 trees in signal path); in-leaf (a), and defoliated (b). Legend as in Figure 3.

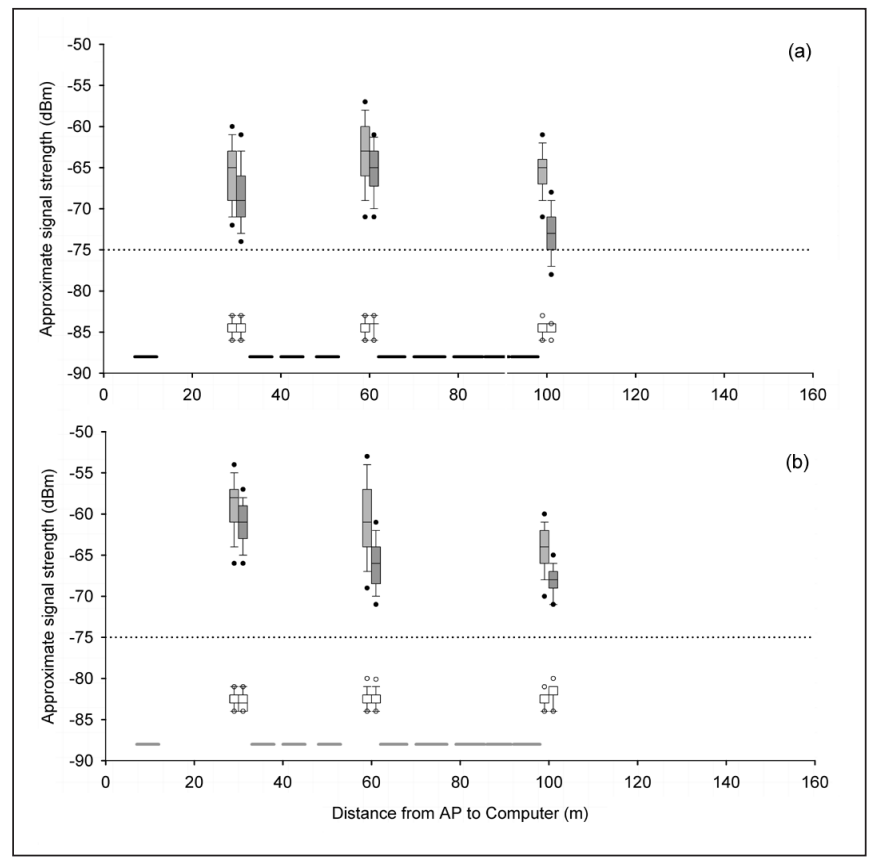

Figure 6. Effects of medium-sized street trees (Liquidambar styraciflua), in-leaf (a), and defoliated (b), on signal \& noise levels $(1,4$, and 9 trees in signal path). Legend as in Figure 3. 
The presence of leaves resulted in slightly (but not significantly) higher attenuation than was seen with defoliated broadleaf trees, which was another expected result, as signal attenuation is largely attributed to water in the leaves (Dobkin 2005).

Observed signal attenuation was considerably lower than that reported in previous studies. This may reflect the advances in Wi-Fi hardware since the publication of previous works. It is also likely that these measurements were less precise than those by the RF engineering researchers (Dalley et al. 1999; Perras and Bouchard 2002) who used purpose-built experiments. For example, this experimental setup did not exclude the possibility of RF phenomena such as Fresnel zones (that are formed around obstacles, including trees), multipath reflections, or refraction around obstacles (Dobkin 2005), any of which could have an enhancing effect on RF signal, and are usually eliminated in controlled experiments. Instead, this study demonstrates the effect of trees on the performance of a municipal WLAN as a typical user might experience it: some signal attenuation, but no substantial interference with the wireless link.

It must be emphasized, however, that signal attenuation by trees must be taken into account during installation of the municipal Wi-Fi, as is general practice (Blais and Kruse, pers. comm.) and had been done during the installation of Google-Fi

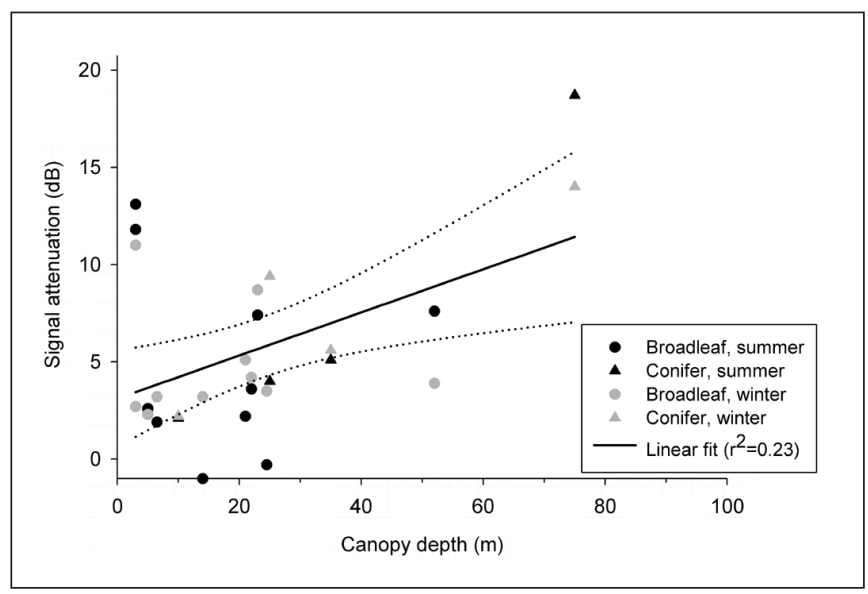

Figure 7. The signal-attenuation increase with canopy depth. Dotted lines are $95 \%$ confidence bands for the fitted line. Note the high outliers at $5 \mathrm{~m}(16 \mathrm{ft})$ canopy depth: this is the large L. tulipifera, shown in Figure 2 and Figure 3.

Table 2: Results of general linear model (GLM) analysis describing the factors that influence the attenuation of Wi-Fi signal, noise, and signal-to-noise ratio (SNR).

\section{Factors tested}

(coefficients for the factors retained in final model)

\begin{tabular}{|c|c|c|c|c|c|c|c|c|c|c|c|}
\hline \multirow{2}{*}{ Metric } & Intercept & $\begin{array}{r}\text { Distance } \\
\text { to AP }(\mathrm{m}) \\
\end{array}$ & Tree count & $\begin{array}{l}\text { Tree size } \\
(\mathrm{S}, \mathrm{M}, \mathrm{L}) \\
\end{array}$ & $\begin{array}{c}\text { Canopy } \\
\text { depth (m) }\end{array}$ & $\begin{array}{l}\text { Broadleaf } \\
\text { or conifer }\end{array}$ & $\begin{array}{l}\text { In-leaf or } \\
\text { defoliated }\end{array}$ & $\begin{array}{c}\text { Leaf area } \\
\left(\mathrm{cm}^{2}\right)\end{array}$ & $\begin{array}{l}\text { Leaf dim } \\
\text { ratio }\end{array}$ & \multicolumn{2}{|c|}{ Model $\mathbf{r}^{2}$} \\
\hline & & & & & & & & & & Full $^{2}$ & Final $^{y}$ \\
\hline$\Delta \mathrm{SNR}$ & -7.836 & - & - & $4.77^{x}$ & $0.123^{w}$ & $-4.89^{x}$ & - & - & - & 0.62 & 0.58 \\
\hline$\Delta$ Signal & -1.308 & - & - & $4.40^{x}$ & $0.124^{\mathrm{w}}$ & $-4.37^{x}$ & - & - & - & 0.64 & 0.55 \\
\hline$\Delta$ Noise & - & - & - & - & - & - & - & - & - & 0.25 & 0.00 \\
\hline
\end{tabular}

z "Full model": includes all variables.

y "Final model": includes only the variables that were retained by the stepwise procedure.

${ }^{x} P<0.001$

${ }^{\text {w }} 0.001<P<0.05$ in Mountain View. This is because tree-caused attenuation necessitates a larger number of APs ("greater AP density," in RF engineering terminology) than would be needed without trees.

In addition, the calculation of how many APs are needed should be based on the canopy depth of full grown trees, even in locations where only newly-planted trees are present. For example, this study observed a "link margin" (the difference between the received signal strength and the $-75 \mathrm{dBm}$ required minimum) between 13 and $10 \mathrm{~dB}$ for AP on Bernardo Street, which is populated with immature Platanus trees. Once fully grown, total canopy depth of these 11 trees could easily expand to as much as 70 $\mathrm{m}(230 \mathrm{ft})$, and the resulting attenuation would then approach 10 $\mathrm{dB}$ (compared to the near-zero attenuation observed at present) - very close to the link margin. Thus, a need for close collaboration between the urban forester and the Wi-Fi network planner during planning and installation of the municipal Wi-Fi network should be stressed. Such collaboration could be useful in the future as well. For example, signal attenuation from trees that grew to obscure an AP could be alleviated by selective pruning, such as crown raising or directional thinning, in tree species that tolerate it.

Continued development of other wireless network technologies, such as $806.11 \mathrm{n}$ and WiMAX (the 802.16 standard; Dobkin 2005) is likely to present continued challenges for urban network managers and to open new issues for future studies of the interaction between urban trees and wireless networks. Some of these alternative wireless network systems operate with low power similar to Wi-Fi, but differ from Wi-Fi in signal frequency and data handling (Dobkin 2005), and thus may differ in their susceptibility to signal attenuation by urban trees. Other directions for future work include evaluating the importance of differing tree crown architecture, and leaf size and position to signal attenuation. Depending on their location, such studies could include palms (e.g., Washingtonia spp., Roystonea regia), evergreen broadleaf species (e.g., Magnolia spp., and Ficus spp.), and species with densely branched fine canopies (e.g., Cercidium floridum). Trees with pendulous leaves (e.g., most of the Eucalyptus species), or finely compound leaves (e.g., some Accacia species, Jacaranda mimosifolia) should also be examined for their potential to attenuate Wi-Fi signal.

City arborists remain keenly interested in improving the performance of urban trees, and one means to achieve this goal is to minimize the conflict with "grey infrastructure", an idea encapsulated in the slogan "right tree-right place." Although generally positive, this concept nevertheless has resulted in 
some unintended consequences, such as a gradual avoidance of large trees, for fear they might interfere with aboveground utility lines (see Kuhns 2007, for a practical approach). Municipal Wi-Fi networks appear to be a part of city infrastructure that, if properly planned, is entirely compatible with (even) large urban trees. Municipal Wi-Fi represents an opportunity to integrate new urban technology into existing or newly planted treescapes while ensuring a conflict-free interaction between the two infrastructure components for the entire life of the trees.

\section{NOTE ON MEASUREMENT UNITS}

RF signal strength can be expressed in watts (W), but because the power levels encountered in RF engineering vary over a range of as much as a billion-fold (Dobkin, 2005), logarithmic units called decibels (dB) are most commonly used to express this change in power (i.e., "gain"):

Gain $(\mathrm{dB})=10 \cdot\left[\log _{10}(\right.$ measured power/reference power $\left.)\right]$.

A three- $\mathrm{dB}$ change represents a doubling of power, whereas $10 \mathrm{~dB}$ change is equivalent to a ten-fold increase or decrease. To make dB values meaningful, a standard "reference power" is agreed upon; in $\mathrm{RF}$ engineering it is one milliwat $(1 \mathrm{~mW}$ $=10^{-3} \mathrm{~W}$ ). The resulting units are designated $\mathrm{dBm}$ ("decibel referenced to $1 \mathrm{~mW}$ "), and because the Wi-Fi system uses very low power (i.e., measured power is much lower than the $1 \mathrm{~mW}$ reference power), the $\mathrm{dBm}$ values for Wi-Fi are negative, varying from the high of about $-30 \mathrm{dBm}$ (one microwatt, $10^{-6} \mathrm{~W}$ ) to the low of about $-90 \mathrm{dBm}$ (one picowatt, $10^{-12} \mathrm{~W}$ ).

Acknowledgments. We sincerely thank Dr. Daniel Dobkin, whose extensive help with data analysis and in understanding the effects of trees on Wi-Fi signal made this study possible. Many thanks also to Tom Blais and Dr. Jay Kruse of Tropos Networks for describing the details of the municipal Wi-Fi hardware and the network in Mountain View. Bruce Hurlburt and Scott Gilliland of the City of Mountain View's Forestry and Roadway Landscape Division greatly helped with the selection of study sites. Profs. Nicholas Mills and Perry de Valpine of the University of California, Berkeley, provided invaluable statistical advice. The manuscript was greatly improved by the thoughtful comments of two anonymous reviewers. The idea for this study came from Dr. Rajeev Koodli, of Starent Networks, who suggested the potential for the interaction of urban trees and municipal Wi-Fi networks.

\section{LITERATURE CITED}

Costello, L.R., and K.S. Jones. 2003. Reducing Infrastructure Damage by Tree Roots: A Compendium of Strategies. Western Chapter of the International Society of Arboriculture, Cohasset, CA. 119 p.

Dalley, J.E.J., M.S. Smith, and D.N. Adams. 1999. Propagation losses due to foliage at various frequencies. pp. 267-270 In Proceedings of the IEEE National Conference on Antennas and Propagation (31 March-1 April 1999, University of York, York, UK).
Dobkin, D.M. 2005. RF Engineering for Wireless Networks: Hardware, Antennas, and Propagation. Newness, San Francisco, CA. 448 p.

Grabosky, J., and N. Bassuk. 1995. A new urban tree soil to safely increase rooting volumes under sidewalks. Journal of Arboriculture 21:197-201.

Kim, R. 2008. Cities have to bid bye-bye to free Wi-Fi. San Francisco Chronicle. www.sfgate.com/cgi-bin/article.cgi?f=/c/a/2008/06/12/ BU681140TT.DTL\&feed=rss.business (accessed 9/23/2008).

Kuhns, M. 2007. How to Fit Large Trees Into Landscapes. extension.usu. edu/forestry/Presentations/Assets/Large\%20Trees\%20and\%20Communities.07.pdf (accessed 9/17/2008)

Lesser, L.M. 2001. Hardscape damage by tree roots. Journal of Arboriculture 27:272-276

Oklahoma City. 2008. Oklahoma City now operational with world's largest municipal Wi-Fi mesh network. www.okc.gov/news/2008_06/ oklahoma_city_wi_fi_mesh_network.html. (accessed 9/23/2008).

Perras, S., and L. Bouchard. 2002. Fading characteristics of RF signals due to foliage in frequency bands from 2 to $60 \mathrm{GHz}$. pp. 267-271 In Proceedings of the 5th International Symposium on Wireless Personal Multimedia Communications (27-30 Oct. 2002, Honolulu, Hawaii).

Randrup, T.B., E.G. McPherson, and L.R. Costello. 2001. A review of tree root conflicts with sidewalks, curbs, and roads. Urban Ecosystems 5:209-225.

Sydnor, T.D., D. Gamstetter, J. Nichols, B. Bishop, J. Favorite, C. Blazer, and L. Turpin. 2000. Trees are not the root of sidewalk problems. Journal of Arboriculture 26:20-29.

Urban, J. 2008. Up By Roots: Healthy Soils and Trees in the Built Environment. International Society of Arboriculture, Champaign, IL. 479 p.

Wagar, J.A., and P.A. Barker. 1983. Tree root damage to sidewalks and curbs. Journal of Arboriculture 9:177-181.

Igor Laćan (corresponding author)

Postdoctoral Researcher

University of California, Berkeley

Department of Environmental Science,

Policy and Management

137 Mulford Hall \# 3114, Berkeley, CA 94720-3114, U.S

ilacan@nature.berkeley.edu

\author{
Joe R. McBride \\ Professor \\ University of California, Berkeley \\ Department of Environmental Science, \\ Policy \& Management \\ and Department of Landscape Architecture \\ \& Environmental Planning \\ 137 Mulford Hall \# 3114, Berkeley, CA 94720-3114, U.S. \\ jrm@nature.berkeley.edu
}


Résumé. Les conflits entre les arbres de villes et les infrastructures demeurent un problème en foresterie urbaine. Le Wi-fi municipal, un système informatique sans fil à l'échelle de la ville, pourrait devenir une composante de l'infrastructure urbaine; et parce que les arbres peuvent diminuer les signaux Wi-fi, il existe un conflit potentiel entre les arbres urbains et le Wi-fi municipal. Cette étude examine l'atténuation des signaux Wi-fi dans la ville de Mountain View en Californie en positionnant un ordinateur équipé d'un système sans fil de manière à ce que les arbres obstruent la ligne du signal entre l'ordinateur et l'émetteur Wi-fi. L'atténuation du signal variait de $<2 \mathrm{~dB}$ à $19 \mathrm{~dB}$ (moyenne de 5,6 dB), et ce dépendant du nombre et des types d'arbres présents. Même si les arbres atténuaient significativement les signaux, ils ne diminuaient pas la force moyenne du signal sous la barre des $-75 \mathrm{dBm}$ (le minimum pour une connexion Wi-fi) dans chacun des tests. Un modèle linéaire général $\left(r^{2}=0,55\right)$ indique que certaines caractéristiques de l'arbre (dimension de l'arbre, densité de la cime, type de feuilles) mais pas d'autres (nombre d'arbre dans le champ du signal, présence, dimension et forme des feuilles) aident à expliquer la variation dans l'atténuation du signal. Tant que l'effet des arbres urbains est pris en compte durant la planification de réseaux Wi-fi, les arbres ne devraient pas interférer avec l'opération municipale d'un Wi-fi.

Zusammenfassung. Der Konflikt zwischen Straßenbäumen und Infrastruktur bleibt ein Problem für urbane Forstwirtschaft. Municipal Wi-Fi, ein stadtweites, drahtloses Computernetzwerk könnte Teil der urbanen Infrastruktur werden, und weil Bäume die WiFi-Signale vermindern, existiert hier ein Konfliktpotential zwischen beiden. Diese Studie untersucht die Verminderung des WiFi-Signals in Mountain View, Kalifornien, durch die Positionierung eines drahtlosen Computers in der Weise, dass Bäume die Signalgebung zwischen PC und WiFi Zugangspunkt behindern. Die Signalabschwächung reichte von $<2 \mathrm{~dB}-19 \mathrm{~dB}$ (durchschnittl. 5,6 dB) in Abhängigkeit von der Anzahl und der Art der
Bäume. Obwohl die Bäume die Signale deutlich verminderten, verminderten sie jedoch in keinem durchgeführten Test die durchschnittliche Signalstärke von $-75 \mathrm{dBm}$ (das Minimum für eine WiFi-Verbindung). Ein allgemeines, lineares Modell $\left(\mathrm{r}^{2}=0,55\right)$ zeigte, das einige Baumcharakteristika (Baumgröße, Kronentiefe, Blatttyp) aber nicht andere (Anzahl der Bäume im Signalbereich, Anwesenheit von Blättern, Blattgröße und Form) halfen, die Variationen zwischen der unterschiedlichen Signalminimierung zu erklären. Solange der Effekt von Straßenbäumen bei der Planung von WiFi-Netzwerken berücksichtigt wird, sollten Bäume bei dieser Operation keine Schwierigkeiten machen.

Resumen. El conflicto entre los árboles urbanos y la infraestructura perdura como un problema en la dasonomía urbana. El Wi-fi municipal, una amplia red inalámbrica de computadoras, puede convertirse en parte de la infraestructura urbana, y debido a que los árboles pueden disminuir las señales Wi-Fi, existe un conflicto potencial entre los árboles urbanos y el Wi-Fi municipal. Este estudio examina la atenuación de las señales Wi-Fi en la Ciudad de Mountain View, California, U.S. mediante el posicionamiento de una computadora equipada con sistema inalámbrico con la señal obstruida por los árboles (LOS, pos sus siglas en inglés) entre la computadora y el punto de acceso de la señal Wi-Fi. La atenuación de la señal varió de $<2 \mathrm{~dB}$ a $19 \mathrm{~dB}$ (media: $5.6 \mathrm{~dB}$ ), dependiendo del número y tipo de árboles presentes. Aunque los árboles atenuaron significativamente las señales, no disminuyeron el promedio debajo de -75 dBm (el mínimo para una conexión Wi-Fi) en cualquiera de las pruebas. Un modelo lineal general $(\mathrm{r} 2=0.55)$ indicó que algunas características de los árboles (tamaño, densidad de la copa, tipo de hoja), pero no otros (número de árboles en LOS, presencia de hojas, forma y tamaño de la hoja) ayudaron a explicar la variación en la atenuación de la señal. En la medida en que el efecto de los árboles urbanos es tomado en cuenta durante la planeación de las redes Wi-Fi, los árboles no deberían interferir con la operación municipal del Wi-Fi. 